$\begin{array}{ll}\begin{array}{l}\text { Biosphere } 2 \\ \text { Columbia set to } \\ \text { continue running } \\ \text { born-again centre } \\ p 567\end{array} & \begin{array}{l}\text { French genes } \\ \text { Controversy over } \\ \text { plan for access to } \\ \text { sequence data } \\ p 569\end{array} \\ p 570\end{array}$

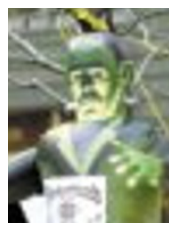

\title{
NASA facing awkward questions as hopes for Mars lander fade
}

\section{Washington \& Munich}

Hopes were fading early this week that ground controllers will ever hear from the Mars Polar Lander (MPL) and two small penetrator probes. The craft arrived in the vicinity of Mars last Friday (3 December), and then vanished without trace.

Although last-ditch efforts to contact the robots will continue for up to two weeks, US space officials face the likelihood that all four spacecraft sent to Mars this year are lost.

The failure of the \$165 million MPL and $\$ 30$ million Deep Space 2 probes, coming after the embarrassing loss of the $\$ 125$ million Mars Climate Orbiter in September (see Nature 402, 221; 1999), would be a severe blow to NASA's plan to visit Mars every two years, and may prompt a re-evaluation of the agency's entire science programme.

An accident review board similar to the one for the climate orbiter will almost certainly be set up, but there will be far less information on which to base the autopsy. Partly as an economy measure, the MPL had no means of communicating with Earth during its final descent to Mars.

With no data, engineers do not know if the probes and lander separated from one another as planned, or if the lander's novel descent engine worked properly. The terrain may have been too rough for the MPL to land upright, and the probes may have been buried in sand or lost in a steep crater.

NASA hopes to use the camera on the Mars Global Surveyor to search for the lander's shadow or its parachute. But spotting the vehicle or its debris from orbit is a long shot. NASA may therefore never learn what went wrong - a troubling prospect, as construction of a similar lander, to be launched in 2001 , is already under way.

The questions are likely to go deeper than the cause of this accident. Planetary scientist Ron Greeley, of Arizona State University, says that if the MPL is declared dead there will probably be several outside reviews. Greeley was on the science team for the MPL, and chairs a committee to advise NASA on its Mars programme.

"We want to see first what the problem with the system was, and how we got to where

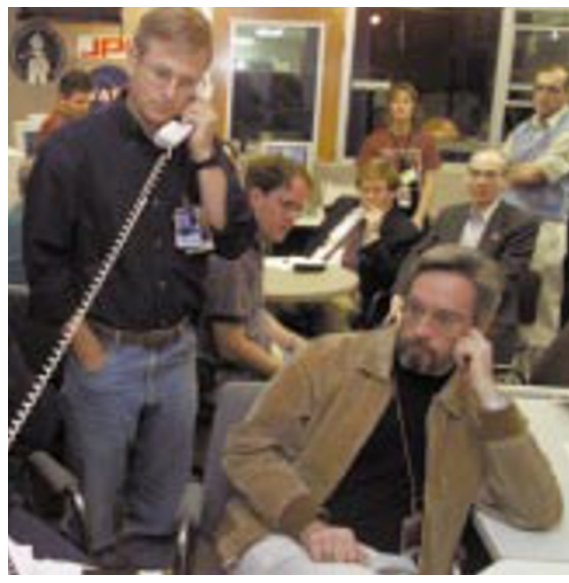

Anybody there? The Mars Polar Lander team wait in vain for news of their spacecraft.

we are today," he says. "We also want to see how the overall strategy might be re-examined from a scientific perspective."

NASA's philosophy of 'better, faster, cheaper' space missions is also likely to come under scrutiny. With the increasingly gloomy prospects for the MPL, a number of scientists are questioning whether the agency's economy drive has gone too far, increasing the risk of costly mistakes.

Kristian Schlegel, a spokesman for the Max Planck Institute of Aeronomy, in Katlenburg-Lindau, Germany, which built the lander's robotic arm camera, says that "the lost opportunity for scientific results" hurts more than the money. The camera cost around DM1 million (US\$520,000).

But Schlegel does not think that there will be a loss of public confidence in unmanned space missions in Europe. Peter Wenzel, head of Solar System Sciences at the European Space Agency, believes that the agency's Mars Express mission - the first of its cheaper, flexible missions, due for launch in 2003 - will continue as planned.

Wenzel says: "We will need to look carefully at our plans to make sure that no corners are cut." The flexible European missions have lower costs "but risks are taken with responsibility," he says.

Beginning with a Soviet attempt in 1988 , seven of the last ten missions to Mars have failed.

Tony Reichhardt \& Alison Abbott

\section{France to lift embryo research ban?}

\section{Paris}

France's 1994 ban on human embryo research should be lifted, according to the Conseil d'Etat, one of the three arms of the country's supreme court. Its aim is to allow scientists to pursue the therapeutic promise of human embryonic stem cells.

The recommendation is one of the main conclusions of a report adopted last week by the body's assembly general. Lionel Jospin, the prime minister, commissioned the report in preparation for a parliamentary debate next year that will lead to a revision of France's bioethics legislation.

The legislation was designed so that it could be updated in response to scientific progress and shifts in moral attitudes. The report recommends that embryo research be allowed for stem-cell research under strict conditions.
Research would only be allowed on surplus embryos. There are 30,000 of these in cold storage in France, left over from in vitro fertilization by parents who do not wish to have them implanted. Implantation of experimental embryos to produce children would be banned.

The report also recommends allowing embryo research aimed at improving reproductive medicine. It proposes the creation of a body, akin to the UK Human Fertilization and Embryo Authority, that would approve research protocols on a caseby-case basis.

The original bioethics laws were adopted under a conservative government, dominated by Roman Catholic ideas. But the national assembly now has a Socialist majority, with a traditionally more liberal stance on embryo research. Declan Butler 